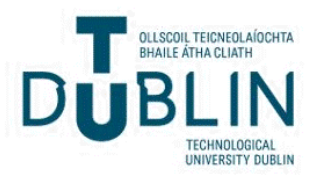

Technological University Dublin ARROW@TU Dublin

\section{Understanding the Heat - Mentoring: A Model for Nurturing Culinary Talent}

Máirtín Mac Con lomaire

Technological University Dublin, mairtin.macconiomaire@tudublin.ie

Follow this and additional works at: https://arrow.tudublin.ie/tfschafart

Part of the Food and Beverage Management Commons

\section{Recommended Citation}

Mac Con lomaire, M. (2008) Understanding the Heat - Mentoring: A Model for Nurturing Culinary Talent. Journal of Culinary Science \& Technology. Vol. 6, No. 1. pp.43-62, DOI: 10.21427/d7dq9k

This Article is brought to you for free and open access by the School of Culinary Arts and Food Technology at ARROW@TU Dublin. It has been accepted for inclusion in Articles by an authorized administrator of ARROW@TU Dublin. For more information, please contact arrow.admin@tudublin.ie, aisling.coyne@tudublin.ie, gerard.connolly@tudublin.ie.

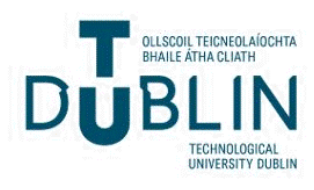




\title{
Understanding the Heat-Mentoring: A Model for Nurturing Culinary Talent
}

\author{
Máirtín Mac Con Iomaire
}

\begin{abstract}
What is the role of work-placement mentoring in nurturing the next generation of Culinarians in order to improve the culinary profession? Is fear and intimidation acceptable in a professional kitchen? What is meant by professional kitchen? Can the reasons behind the high levels of staff turnover in kitchens be identified? What is meant by the term mentoring? In this article I hope to address these questions, and to discuss mentoring as a model for nurturing culinary talent. I draw upon both personal experiences and those of students who have experienced mentoring as part of the Professional Internship Module of the BA in Culinary Arts in the Dublin Institute of Technology to support my position.
\end{abstract}

KEYWORDS. Culinary, mentoring, work experience, bullying

\section{INTRODUCTION}

What is the role of work-placement mentoring in nurturing the next generation of Culinarians in order to improve the culinary profession? Is fear and intimidation acceptable in a professional kitchen? What is meant by professional kitchen? Can the reasons behind the high levels of staff turnover in kitchens be identified? What is meant by the term mentoring?

Máirtín Mac Con Iomaire is a Lecturer in Culinary Arts at the Dublin Institute of Technology. He can be contacted at Cathal Brugha Street, Dublin, 1, Ireland (E-mail: mairtin.macconiomaire@ dit.ie).

Address correspondence to: Máirtín Mac Con Iomaire at the above address.

Journal of Culinary Science \& Technology, Vol. 6(1) 2008

Available online at http://jcst.haworthpress.com

(C) 2008 by The Haworth Press, Inc. All rights reserved. 
In this article my aim is to address these questions, and to discuss mentoring as a model for nurturing culinary talent. My research draws upon both personal experiences and the recorded experiences of students who have experienced mentoring as part of their Professional Internship Module of the BA in Culinary Arts in the Dublin Institute of Technology to support my position.

This article is written in the context of exceptional growth, labour shortages and high staff turnover within the Irish hospitality industry (Keating and McMahon 2000). Labour shortages and high staff turnover within the hospitality business is not only an Irish problem but also an international one (Hoque 2000). An employment survey (CERT, 2002) forecasted the need for 125,000 new employees in the Irish catering industry in the five years up to 2007. Of this number 100,000 would be due to labour turnover. The report identifies the areas of restaurant service and kitchen as areas with particularly high levels of labour turnover.

It is difficult to see the forecasted numbers being achieved unless all of the factors responsible for high staff turnover are clearly identified and addressed. CERT, the state tourism training agency, has carried out a number of 'where are they now?' research studies covering the period from 1966-1998. The main reasons given by respondents for leaving the industry were better pay elsewhere $(22 \%)$ followed by irregular $(17 \%)$ or long $(15 \%)$ hours in the tourism industry. The majority of respondents $(56 \%)$ had worked in between three and eight different establishments since graduating. The principle reason noted above for leaving the industry concerned wages. Many employers historically saw college students and apprenticeship courses as a form of cheap labour/a steady stream of fodder for the industry. This attitude was particularly prevalent during periods of high unemployment. Ireland in 2007 is nearly at full employment and over $30 \%$ of our hospitality workers are foreign nationals. Employers now realise the importance of attracting and keeping staff, and mentoring is one tool that I suggest may assist them with this challenge.

\section{The Culinary Underbelly}

The deeper issues of bullying and kitchen violence seem to have been either ignored or sanitised from official reports. My second work-placement during college was in a gourmet restaurant. This was my first experience of split shifts and the culture in this kitchen was one of fear and intimidation. The head chef was prone to violent outbursts and had a propensity to smash the odd plate off the wall for dramatic effect. I dreaded going back to work in the afternoons, because his repeated ridiculing had undermined my selfconfidence, and this often led to my falling behind in my work. I began to come back to work an hour earlier just to keep ahead, and my fortunes changed for the better. The following year I worked with a similarly volatile chef, who happened to be French. I learned a great deal about food in these two establishments but I also concluded that although they were both excellent cooks, their behaviour disqualified them from being considered professionals in the accepted use of that term. In my opinion violence or abusive behaviour has no place in a kitchen. A really good chef is well organised and instills confidence in his/her brigade. Like many a good teacher or parent, the good chef would only have to give a disapproving look to make one shape up! A.A. Gill, the critic, once generalised that chefs as a breed are socially inept and not very clever, and whilst arrogant in their kitchens, they are hopelessly gauche outside. Galvin (2003) refutes this and states that most good chefs are amazingly bright, generous, energetic individuals whose work is fiercely demanding. He explains what Gill considers gauche as merely not suffering fools easily.

Kitchens are hierarchical organisations and are run on authoritarian precepts. The word chef means chief, and there can only be one chief in a kitchen. Anthony Bourdain (2000) clearly states his perceptions of what he expected when joining the hospitality industry: apprenticeship in France, evil drunk chefs, crackpot owners, low pay, and terrible working conditions. Towards the end of his book he realises he had spent years as a mass caterer compared to the level Scott Bryan had reached at 'Veritas', where the menu, the business, the whole concept was built to compliment the wine list. To use the clothing metaphor, previously used by Gillespie (1994), Bourdain was working in the culinary equivalent of J.C. Penneys whereas Scott Bryan's haute cuisine is the culinary equivalent of haute couture.

The role of the professional chef, whether working in mass catering or haute cuisine, is recognised as demanding, stressful, and sheer hard work (Bates and Dutson 1995). Johns and Menzel (1999) acknowledge kitchens as stressful places, because of the variable demand and the tight specifications placed upon the product: workload surges at peak times leave kitchens temporarily understaffed and a high turnover of employees mean that the available staff may lack necessary skills. Another interesting source of stress identified in the research, particularly among leading restaurants, is the 'constant scrutiny' by Michelin inspectors, which in turn could precipitate violence. Johns and Menzel (1999) conclude that the acceptance of violence in top class kitchens is linked with the cult of the individual and artistic temperament. 
'There seems to be a deep seated cultural acceptance of violence as part of the striving of a perfectionist or the legitimised whim of iconised individuality.'

Kitchen violence became a topical issue in 1995 following the screening of a television programme 'The Big Story' which took the viewers behind the scenes of some of Britain's top restaurant kitchens (Crossley 1995). Physical violence was shown again on 'Boiling Point' a documentary charting Gordon Ramsay's search for three Michelin stars in his new restaurant-filmed during 1998/9 (Buford, 2007). Ramsay's current programmes feature verbal violence and its widespread unquestioned acceptance among the viewing public is worrying. I strongly condemn such violence. I am concerned that novices in the field learn that such behaviour is unacceptable. My aim is to prevent the novices from perpetuating the myth, modelling themselves on violent chefs, thereby maintaining a vicious circle of bullying.

\section{Learning from History versus History Repeating Itself}

Lessons can be learnt from studying the history of professional cookery. Despite the supreme importance of food in France throughout the seventeenth and eighteenth century, chefs were underprivileged people, only remembered if they wrote cookbooks (Blake and Crewe, 1978:14). Cooking was a difficult and potentially rewarding métier, but Wheaton (1983:111-2) proposes 'the opportunity to experiment with an abundance of ingredients would have had the quality of fantasy in a society where starvation was an omnipresent threat to most people'. She suggests that kitchen workers were mostly guaranteed a full stomach, a warm place to sleep, and the opportunity of pilfering food for hungry mouths at home (Wheaton, 1983:110). Crespin (1641:14-16) cited in Wheaton (1983:110-11) describes the lively social life in kitchens: full of love affairs, good dining-at their masters expense-and camaraderie where the staff covered for one another. Some culinary professionals, however, took their positions very seriously. Vatel, maître d'hôtel to the Prince de Condé, described as 'the epitome of the organisational skills required of chefs and the romantic model of the perfectionism which drives them' took his own life when he thought the shipment of seafood had not arrived whilst entertaining Louis XIV in 1671. The fish arrived just after he had thrown himself on his sword (Wheaton, 1983:145). Blake and Crewe (1978:13) argue that the story of Vatel, which is usually thought to typify the dedication of chefs can equally be seen as a story of the disdain of princes for their employees. Vatel's corpse was buried hastily in an un-marked grave, because there was a tradition that the king did not stay where there was death in a house.

Chefs historically were known to drink because of the unbearable heat and a culture where wine seemed as available as water. In Lord Kildare's household in mid-eighteenth century Ireland, the cook was allowed one quart of ale at $11 \mathrm{am}$ and another at $2 \mathrm{pm}$, and by 1772 the cook was allowed one quart of ale or strong beer between $1 \mathrm{pm}$ and $2 \mathrm{pm}$ 'if he desires', whereas small beer (a very light beer) was available to the kitchen staff and nearly anyone who so wished. Any malt liquor remaining after the Duke or Duchess dined was allowed to be taken to the stewards room where the upper servants ate (McCarthy, 2003:123). Up until recently a leading Dublin hotel had a 'sweat pint' system as part of the chef's terms and conditions of employment (Field notes 26 April 2003, p.3). This system and culture contributed to high levels of alcoholism among chefs. It has long been mooted that as long as there were hungry waiters, there would never be a thirsty chef. This inadvertently led to the invention of the Irish Coffee. The chef received his whiskey camouflaged in coffee topped with cream. On being found out the chef said he was inventing a new dish, an explanation that the management were keen to exploit.

Kitchens are not the only problematic part of the hospitality industry. Mars and Nicod (1984) identified an institutionalised acceptance of 'fiddling' or 'the informal rewards system' among waiters, and state that those who benefit do so with the collusion of management. Gerry Galvin, former restaurateur and consultant chef describes hotel managers as culinary voyeurs, somewhat like the literary critics Brendan Behan described as eunuchs, who knew how the job was done, but could not do it themselves. Chivers (1973) describes chefs as having declined in terms of skill and in terms of status. Mennell (1996:199) agrees with this assessment and suggests that the dominance of management, with its disdain for the craft of cooking, has contributed to this decline in ascribed status.

The genre of the 'celebrity chef' is a fairly recent phenomenon. Many young people are drawn to the industry by the glamour and fame of these 'celebrity chefs'. The reality of the industry can soon cause them to change their mind. Professor David Foskett claimed in Caterer \& Hotelkeeper magazine that 'Jamie's Kitchen', a celebrity chef reality television programme, has set the public's perception of professional cookery education back fifty years. Mennell (1996:197) suggests that although much has been written about the famous individual chefs throughout 
history, the vast majority of practitioners worked extremely hard, under difficult conditions for average remuneration. In hard times, as Wheaton (1983) has outlined, it was considered a good job. A colleague once recalled how his mother advised him to become a chef because he would be well-fed and be in out of the rain. Conditions have vastly improved since the days of the coal fired range, where there was no controlling the heat in the kitchen. Frank Farren, a retired chef (born 1926) recalls the war years when coal was in short supply: ' a ladle of oil under a stockpot would coax it to a fast boil but also fill the kitchen with black smoke' (field notes 28 May 2003 p.4). Marie-Antoine Carême (1783-1833) died before reaching the age of fifty 'burnt out by the flame of his genius and the fuel of his oven (Ackerman, 1988:90; Parkhurst Ferguson, 2006). Technological advances have helped improve working conditions, but unfortunately some aspects of kitchen culture seem to have remained stagnant and escaped serious critique. George Orwell's (1933) description of scurrying waiters and shouting, ill-mannered chefs still has a resonance in some of today's kitchens. Stereotypical tales of screaming chefs and tales of the excitement of a busy kitchens have shocked and enthralled readers ever since, from Bemelmans (1946) to Buford (2007), via Freeling (2002), Bourdain (2000) and Ramsay (2006). Gordon Ramsay's profanities have become catchphrases, so much so that one day in his New York restaurant, a woman shouted from the chefs table-situated just in front of the pass-'Gordon, tell your cooks to fuck off, and I'll leave a thousand dollar tip!' (Buford, 2007:49). Clearly there is a long way still to go in professionalizing the industry.

\section{Motivation and Nurture}

So what are the factors that motivate chefs to continue working in this industry? Mullins (1999) explains the underlying concept of motivation as some driving force within individuals by which they attempt to achieve some goal in order to fulfil some need or expectation. These needs, reminiscent of Maslow's Hierachy of needs, may be:

1. Extrinsic (pay, security etc.)

2. Intrinsic (job satisfaction, personal growth and development etc.) or

3. Social (friendship, relationships, desire for status or dependency).

Armstrong (1996) outlines how extrinsic motivators can have an immediate and powerful effect, but that it does not necessarily last long.
Intrinsic motivators, which are concerned with the "quality of working life', are likely to have a deeper and longer-term effect because they are inherent in individuals and not imposed from outside.

A certain minority of culinary students, however, working in temperamental, stressful up-market gourmet restaurant kitchens, would appear to disprove Maslow's hierarchy of needs theory, since they are willing to trade both physiological and safety needs for the perceived social need of being accepted among their peers. Like some medical interns, such as those depicted in the television programme 'House', they are willing to put up with what would normally be considered 'unacceptable' conditions on the precept of postponed gratification-learning from a master practitioner/unorthodox genius. But only a minority are willing to make this trade off. Despite Ramsay's reputation and behaviour, he has mentored a number of protégées, such as Marcus Wareing, Angela Hartnett, Mark Sargent and Neil Ferguson, who now run his flagship restaurant kitchens for him (Harris, 2002; Buford, 2007). His methods may be unorthodox but he has managed to retain a large number of key staff. Having lambasted a young chef in his New York eatery, he called over the sous-chef and said 'Treat that young man like your little brother. Take him under your wing. Build his confidence.'

In my research, I asked head chefs involved in mentoring the BA Culinary Arts students the question 'what motivates your staff?' The response was as follows:

\begin{tabular}{lccc}
\hline Training/Learning & $54 \%$ & Teamwork and Co-operation & $42 \%$ \\
Good atmosphere & $54 \%$ & Good Communication & $36 \%$ \\
Social aspect (parties, socializing, sport club, football etc.) & $48 \%$ \\
Good Wages & $36 \%$ & Leadership from top down & $30 \%$ \\
Respect & $18 \%$ & A good Appraisal System & $18 \%$ \\
Good Hours & $12 \%$ & & \\
\hline
\end{tabular}

The above response shows that the intrinsic and social needs outweigh the extrinsic needs. The hospitality industry is a low-paid industry but social aspects and teamwork can motivate. Eleanor Walsh from Eden Restaurant explains

'We bring the staff out three times a year (social), have staff meetings once a month, run competitions. When you are buzzing the staff buzz off you.' 
Paul Keogh from Brasserie na Mara believes his staff are motivated by their ability to learn, and influence what goes on the menu.

'We help build a career for good staff and when they eventually decide to move on we help them in choosing their next job. We develop career chefs not industry fodder.'

A chef is responsible not just for the selection, preparation, cooking and presentation of food, but must also for managing manpower, machinery and materials within a tight budget. Chef's performances are measured as much by their profit margins as they are by satisfied customers. The following three factors, in my experience, contribute to making it an even more stressful occupation:

1. Most chefs have received little or no management training. In 1996 I was executive head chef for a catering company, with 26 staff to look after and a turnover of $£ 11$ million. What had prepared me for this? What training had I received in managing people? Although I had attended advanced cookery courses since graduating from the professional cookery course it was clear that I would have benefited from more knowledge of organisational behaviour, and management studies.

2. Communication skills are essential in a kitchen but again formal communication training is very often ineffective. I illustrate this point to my students each year by recalling the tale (which I'm sure is universal) of the chef who asked a new kitchen porter to drain a pot of beef stock. When he returns to see a pot of bones waiting for him he explodes with anger on finding that the porter had poured the liquid ( 8 hours of gentle alchemy) down the drain. Had he clearly communicated that he wanted the stock kept and the bones discarded this situation would not have occurred.

3. One of the chefs' greatest challenges is the deep-rooted culture in catering that the show must go on regardless. This can lead to brigades trying to operate at peak performance whilst understaffed or with broken equipment. Frank Farren recalls the extreme dedication of a Miss Mullins, the manageress of the Central Hotel in Dublin in 1944, who on the day she died had to be restrained from getting out of bed to attend to the Board of Directors meeting that morning (Field notes 28 May 2003, p.2). Similar examples of unnatural dedication are provided more recently by Ruhlman (1997) and Wright (2006).
Erraught (1998) identified the gap in the training and education provision for head chefs. Head chefs have not been equipped in their college training with the management skills necessary to function as effective managers. The most popular chefs' course in Ireland taken either full time or by part-time 'day release', culminating in a Certificate in Professional Cookery, has been a second level training programme run by CERT and offered in various colleges throughout the country. Research in the mid 1990s culminated in the development of an honours degree in Culinary Arts in the Dublin Institute of Technology. This research engaged with the concepts of both mentoring and work-based learning. The literature shows overwhelming agreement on the importance of internships in hospitality education but also highlights the fact that little research has attempted to identify the elements that contribute to a satisfactory internship by collecting first hand reports from hospitality interns (Nelson, 1997). It was decided that with the development of this new degree course, a new model for professional internship also needed to be developed. It was proposed that the students would be assigned mentors with established positive reputations within the industry.

'The internship is one of the key integrating elements of the degree in culinary arts. It is a work based learning programme in a culinary arts professional environment and is a major contributor to the student's personal and professional development.' (CourseDocument, 1998)

\section{Mentoring and Nurture}

But what are the origins of mentoring? The term 'mentor' is over three thousand years old and has its origins in Greek Mythology. When Odysseus went off to fight the Trojans, he left his trusted friend Mentor in charge of his household and his son's education. Mentor's name has been attached to the process of education and care by an older, experienced person. Mentors have been defined as high ranking, influential senior organisation members with advance experience and knowledge, who are committed to providing upward mobility and support to a protégé's professional career (Roche, 1979; Collins, 1983; Kram, 1995). Murray (1991) defines mentoring as

' $a$ deliberate pairing of a more skilled or experienced person with a lesser skilled or experienced one, with the agreed-upon 
goal of having the lesser skilled person grow and develop specific competencies.'

This mentoring relationship can be defined as an intense, lasting, and professionally beneficial relationship between two individuals. In this relationship the more experienced and powerful individual, the mentor, guides, advises, and contributes in any number of ways the career of the less experienced, often younger, upwardly mobile protégé. Given this definition, it is not surprising that mentoring is not a common experience. The relationship requires a long-term reciprocal commitment of energy and time. It requires two people who come together in a mutually opportune time and who respect and enjoy one another enough to spend significant amounts of time together. It requires nurturing.

The BA Culinary Arts, initiated in the 1999/2000 academic year in the School of Culinary Arts and Food Technology, differed drastically from the second level certificate program previously in place. The guiding philosophy of the BA in Culinary Arts is to move beyond the utilitarian and traditional craft-based apprenticeship training in professional cookery towards an academic and scholarly form, which reflects high status knowledge thereby improving culinary arts education (Interim-Report 1998). Hegarty (2001) explains that this new degree is:

"aimed to develop the intellectual capacity of the individual rather than the wrist-to-fingertip drills of the traditional apprenticeship and to maximise the potential of each individual student. Such philosophy has considerable potential advantages for it would enable culinary arts to stake a place for itself in higher education, where culinary arts teachers, for the first time would be taught and trained.'

The programme has a strong student focus based on active student participation and exposure to a variety of teaching and learning opportunities. The aim is to move from the concept of teachers thinking of themselves as 'subject teachers' to becoming facilitators of student learning pursued through the medium of culinary arts (Hegarty, 2001). A programme in culinary arts needs to be a holistic educational experience for the student and not merely focused on the staffing needs of industry (Fuller, 1983). The following quote from Cleminson and Bradshaw (1996) mirrors the professional internship program's philosophy:
'In the first place, learning in the workplace must engage the interest and curiosity of the aspiring professional who must bring to the workplace a body of knowledge which can be challenged and reinterpreted in the workplace through practice and observation of practice.'

The participating establishments are chosen carefully for the quality of the mentoring available rather than the size or status of the establishment. The goal of the programme is to facilitate accelerated learning (McKee, 1999), experiential learning (Kolb, 1984; Boud, Cohen et al., 1993) and reflective practice (Schon, 1983).

Students on the first two years of the course spend six weeks annually on internship in Ireland. Some second year students choose to spend their internship in food related non-kitchen placements. Third year students spend eight weeks on an international internship. Students are required to keep a reflective/learning journal whilst on placement, and have regular meetings with their mentor to discuss progress. At a workshop for new mentors for the second cohort of the Internship programme the Head of School, Mr. Joseph Hegarty, explained that the professional internship differed drastically from previous industry placement:

'We have changed the notion of industrial placement entirely... what happened is that students were taken and put into industry, nobody gave a care about them, then they came back, wrote a report that was usually a collection of brochures about the place, there was no critical assessment, there was no contribution and really and truly there has been no genuine contribution from this industry for the last seventy years.' (JH 23/10/00)

In the early meetings with industry representatives (potential mentors) it took a while to convince some of them to move away from the short term 'what's in it for me now?' attitude to a more long-term strategic vision of increasing the pool of highly educated talented individuals that could help raise standards within the whole industry. Students were placed on a six-week unpaid placement in many of the top establishments around the country. The mentors were asked to pay them not in monetary terms but by investing time in the students' learning. Research from the first two iterations highlighted the importance of students meeting their mentors, building a rapport prior to commencing the internship, and also the importance of receiving a proper induction (Mac Con Iomaire, 2001a). Induction 
involves the introduction of a new member of staff to the culture and environment, its policies, practices and to other members of staff. Mullins (1999:691) writes:

'A warm welcome, initial introductions, and a properly planned and designed induction programme will do much to reassure members, and aid their motivation and attitudes to their work performance'.

The Ritz-Carlton group place great importance on the period of induction viewing the first few days as critical, as newly hired workers - are like sponges'-will absorb good and bad practice.

Similar research (Mac Con Iomaire, 2001b) suggests that this internship programme causes industry participants to re-think how they treat existing staff and how their organisations might benefit from engaging with mentoring programmes. Also, this research showed that even in a climate of labour shortages, nearly all establishments involved in mentoring our students had good loyal staff and remarkably low levels of staff turnover. Zey (1984) confirms these findings concerning mentoring programmes and states that the result of the mentoring relationship can benefit the protégé, the mentor and the organisation. The protégé receives knowledge and skills, support, protection and promotion. The mentor may realise assistance on the job, prestige and loyalty. The organisation achieves development of employees, managerial success, reduces staff turnover, and increased productivity. Dr. Linda Phillips-Jones highlights some of the benefits of mentoring as follows;

- 'Organisations that want to attract high performers are offering (along with high salaries) other perks including formal mentoring opportunities. High potential candidates want to know they'll be developed by their new employers.

- Formalised mentoring shortens mentees' learning curves. Mentees become more productive sooner because they gain knowledge, skills, and core values more quickly from mentor-guided experiences than from longer-term, traditional methods.' (Phillips-Jones, 2000)

\section{Recognising the Master-Performer}

One way of getting at key core attributes of the mentor is through the concept of master performer. Toohey (1999:73) points out that the idea of a master-performer can be used not just for analysing purely vocational task-based roles but in any discipline-philosopher, historian, economist, physicist, choreographer, physician and so forth. Sometimes it is possible to recognise real role models, but more often industry mentors are likely to be envisaged as a composite performer, an imaginary figure who exemplifies the kinds of skills and knowledge, values and attributes which are characteristic of a mentoring personality-or perhaps an accomplished performer. Toohey (1999:74) suggests that mentors and mentoring developers need to ask questions like:

What roles do master-performers/mentors undertake?

What distinguishes excellent performers from merely average?

The outcomes of exercises like the analysis of the master-performer and the desired qualities of graduates need to be formulated into the general aims or goals for the internship programme. They will be useful if they positively influence teaching and learning strategies during internship implementation. One of the negative influences can arise when those who come later to mentor on the course have not shared the experience of formulating the aims and objectives. Holding mentoring workshops/refresher courses for new and existing mentors can help to alleviate or avoid this occurance.

Is there a universal method of identifying what a master chef is? Are there too many segments within the industry for any one person to master? How would a three-star Michelin chef fare providing three thousand meals a day in a large hospital? Does the industry have a universal recognised standard of excellence that is recognised by everyone? A certified system for master chefs (CMC) exists in the form of a ten day exam run by the Culinary Institute of America (CIA), which aimed to create exactly that. Ruhlman (2001) notes that opinion is divided on the value of the CMC credential. Only about $7 \%$ of certified master chefs actually run successful restaurants, the rest work in education, research and development, or corporate or institutionalised catering. A further difficulty is that some chefs like Heston Blumenthal, Nico Ladenis, or Raymond Blanc manage to achieve culinary greatness in the form of Michelin stars and respect from their peers without following the traditional apprenticeship or college training. One common characteristic that Wright (2006) pinpoints in Gordon Ramsay, Heston Blumenthal, Marcus Wareing and Shaun Hill is gritty determination, obsession, and tenacity. Carberry (2001) found that many eminent chefs possess strong entrepreneurial characteristics. Would these characteristics make them good mentors, or to use a sporting analogy, can only some great athletes become great coaches? 
Most catering staff who become trainers or adopt the role of mentor do so as an act of altruism, since many hotel owners / managers / chefs do not support so-called 'management' training. Sharing knowledge in the catering industry can be dangerous, according to Fine (1996) because some hotel managers often replace high-paid workers with low-paid ones. Good mentor/mentee relationships are often serendipitous: a chance encounter that may or may not contribute to making a life. I propose that careful matching of mentor with mentee can increase the rates of successful end results for all parties.

\section{Student Feedback}

During my research I asked students to describe what the highlight of their internship was in order to identify the benefit of the internship from the students' perspective. The main themes emerging from this question were:

1. Gaining confidence and a sense of achievement particularly when given feedback or thanked for the job done.

2. The excitement of doing something for the first time.

3. Being challenged and rising to the challenge.

There were many comparisons between the highlights of the first and second iteration particularly learning new things and new ways of learning. The students really enjoyed the sense of teamwork in professional practice and the experience of working in a real live professional environment.

Students were also asked to comment on the lowlight of the internship. The main themes emerging from this question were:

1. The lack of pay.

2. The lack of time for learning.

3. Monotony of the work or insufficient work.

4. Feeling lonely, finding the work and environment tough, extremely tiring sometimes leading to tears.

Since fine-tuning certain aspects of the internship based on feedback from the first two iterations, our programme at the DIT is running extremely well. Mentors have become more comfortable in their roles and we are continuously attracting new mentors to the programme as it develops. Students have benefited also as the following excerpts from student's reflective diary illustrates how the learning progressed:
Day 1

'Today is my first day. I was nervous but not as bad as last year. One of the most crucial aspects that I want to receive from work experience is to increase my confidence. The head chef approached me at the end of my shift and asked me what exactly I would like to learn...he is very nice in that he doesn't want me doing too much as he doesn't want to exploit me, which I thought was very thoughtful.'

Day 2

'I am slowly beginning to learn the lunch menu by observing. The layout of the kitchen is a bit annoying; but I am going to try staying positive at all times. I like working here but cannot see myself staying for the summer, that is if I was asked.'

Day 3

'I feel a lot more easy now; I'm getting familiar with the lunch menu. Hopefully next week I will feel a lot more settled.'

Week 3

'This week has been going very fast. I am given more responsibility. I am getting to do the vegetarian and potatoes on my own. I am happy I am fitting in well. I believe I am learning a lot, I can see an improvement in my knife skills.'

Week 4

'I feel really good when I am given the responsibility to do so many tasks, it makes me feel part of the team and that they depend on me. I am getting more confident in myself and in the work I do.'

\section{Week 5}

'I got to do two new tasks today. I find everything takes twice as long when you don't know what you are doing. I had to even ask them to show me examples, but it has to be done, I would rather ask them than do the job wrong. Tomorrow we have a busy lunch. I feel part of the team.'

Week 6

'Today was a good day for me. I got the responsibility of doing pasta to make noodle cakes. I am feeling more confident and I am enjoying myself as well. It was a slow process starting off but looking back I believe that I have gained a great deal and learned not just about my ability but also what it is like in a new environment. It has been a valuable lesson in my course.' 
This student was asked to stay on for the summer at the end of the professional internship period and accepted the offer.

During the first year of the programme $80 \%$ of students enjoyed their internship and $90 \%$ of industry found their role as mentor fulfilling. One industry respondent didn't find the role fulfilling because he wasn't sure that he was making any headway with the student. The number of students who enjoyed the internship had risen to $90 \%$ in the second iteration and this number has risen to $96 \%$ among the fourth cohort. The general mood is summed up by the following comments:

'It was a blast, I love the place, the people, the work everything.'

'I learned an extreme amount and got on well with everyone.'

'The weeks have flown by. The staff were very friendly and encouraging. There was one night that was very busy and the buzz from the kitchen and service was brilliant.'

Of the few who didn't enjoy their internship the reasons are explained in their comments:

'Kind of in-between: I got to see an actual kitchen at work but I sometimes felt like I didn't have a clue. I like to know what I am doing.'

'Low standard of food, I did the same thing every day.'

'I felt he didn't want me to learn his tricks of the trade as I wasn't going to be there long term.'

This last comment shows there are still some of the old style chefs around who feel that to have knowledge is to have power. I would suggest that sharing knowledge is much more empowering.

\section{Conclusion}

In conclusion the role of mentoring in nurturing culinary talent, although not fully researched, is in my opinion time well spent. Student feedback is indicative of this and current doctoral research within this area in the Dublin Institute of Technology shall hopefully throw more light on the subject. The philosophy of mentoring needs to be generalised into the wider culinary arts community in order to transform the nature of the kitchen into a nurturing environment. This is an ongoing project and is not going to be completed overnight. Let me make it clear, there is no place for violence or bullying in any kitchen. Bourdain (2000:260, 265) points out that there was no bullying in Scott Bryan's kitchen, and that one of the main reasons Bourdain didn't become a three-star chef was he went for quick money instead of postponing the gratification and learning his craft well before moving up the ranks.

Through my research I have identified that establishments that provide good learning and working environments have less difficulty in recruiting and retaining staff. The experience gained from mentoring students from the BA Culinary Arts has caused employers to reflect on how they treat existing staff. Successful mentoring does take time and depends on matching the right mentor with the right mentee. We have begun to encourage industry away from the short term 'what's in it for me?' mindset to a more long-term vision of making the industry more professional. Graduates from the programme are now becoming mentors to the current cohort of students and will be the mentors of the future. A number of graduates from the programme have worked with Heston Blumenthal in 'The Fat Duck' and report that the best practice in management theory is in operation there, where the highest standards are being reached without resorting to any form of bullying, intimidation or violence. Once these graduates model themselves on what they have learnt and experienced in such exemplary kitchens, the future of food looks brighter.

Mentors need training and encouragement from college lecturers, and they in turn need support and encouragement from college management. All stakeholders need to be continuously constructively critical of the process and look at other professional fields to examine whether they might learn from their structures and culture in order to improve best practice (Hegarty 1998). Changes made fine-tuning the process need to be documented and disseminated to the wider culinary community, ideally by culinary arts practitioners. Let us hope nurture will continue to influence nature for the better. I propose that the philosophy of mentoring needs to be generalised into the wider culinary community in order to transform the nature of the kitchen into a nurturing environment.

\section{REFERENCES}

Ackerman, R. (1988). The Chef's Apprentice. London, Headline Book Publishing PLC. Armstrong, M. (1996). Personnel Management Practice. London, Kogan Page. 
Bates, I. and J. Dutson (1995). "A Bermuda Triangle? A case study of the disappearance of competence-based vocational training policy in the context of practice." British Journal of Education and Work 8(2): 41-59.

Bemelmans, L. (1946). Hotel Bemelmans. New York, Viking.

Blake, A. and Q. Crewe (1978). Great Chefs of France. London, Mitchell Beazley-Artists House.

Boud, D., R. Cohen, et al., Eds. (1993). Using Experience for Learning. Buckingham, Society for Research into Higher Education \& Open University Press.

Bourdain, A. (2000). Kitchen Confidential. London, Bloomsbury Publishing.

Buford, B. (2007). "The Taming of the Chef: Gordon Ramsay cooks for New York." The New Yorker LXXXIII(6): (April 2nd) 46-57.

Carberry, J. A. (2001). What makes an Eminent Chef? An Exploratory Study of the Factors Influencing the Development of Eminent Chefs (unpublished thesis). Culinary Arts and Food Technology. Dublin Dublin Institute of Technology.

CERT. (2002). "125,000 New Recruits Required by Tourism Industry." Retrieved 29 May 2003, www.cert.ie/about_cert/press_releases

Chivers, T. S. (1973). "The Proletarianisation of a Service Worker." Sociological Review 21, 633-656.

Cleminson, A. and S. Bradford (1996). "Professional Education: the relationship between 'academic' and experiential learning." Journal of Vocational Education and Training, $48(3), 249-259$.

Collins, N. W. (1983). Professional women and their mentors. Englewood Cliffs, New Jersey, Prentice Hall.

Course-Document (1998). Document in support of an application to academic council, Dublin Institute of Technology for a Bachelor of Arts Degree in Culinary Arts.

Crespin, I. s. (1641). L'Ecomomie ou le vray advis pour se faire bien servir. Paris

Crossley, G. (1995). "Violence must be controlled." Caterer \& Hotelkeeper 187(3,893): 25.

Erraught, E. (1998). Recognition of the Gap in the Training and Educational Provision for Head Chefs (unpublished Masters Thesis). Dublin: Dublin City University.

Fine, G. A. (1996). Kitchens : The Culture of Restaurant Work. Berkley: University of California Press.

Freeling, N. (2002). The Kitchen and The Cook. London: Big Cat Press.

Fuller, J. (1983). Hotel Management Education. The Management of Hospitality. E. Cassee and R. Reuland. Oxford: Pergamon Press.

Galvin, G. (2003). "Gerry Galvin's Stockpot." Food and Wine Magazine(June): 52.

Gillespie, C. (1994). "Gastrosophy and Nouvelle Cuisine: Entrepreneurial Fashion and Fiction." British Food Journal, 96(10), 19-23.

Harris, D. (2002). "The rise and rise of Ramsay restaurants." Caterer \& Hotelkeeper 191(4237 (7-13 November)): 4.

Hegarty, J. (1998). "Culinary arts / hospitality research: a comparative analysis." International Journal of Hospitality Management, 17(4), 345-347.

Hegarty, J. (2001). Standing the Heat (unpublished Ed.D Thesis). Sheffield: University of Sheffield.

Hoque, K. (2000). Human Resource Management in the Hotel Industry: Strategy, Innovation and Performance. London: Routledge.
Interim-Report (1998). Document in support of an application to Academic Council, Dublin Institute of Technology for a Bachelor of Arts Degree in Culinary Arts.

Johns, N. and P. J. Menzel (1999). "'If you can't stand the heat!' ... kitchen violence and culinary art." International Journal of Hospitality Management, 18(2), 99-109.

Keating, M. and L. McMahon (2000). Human Resource Management Practices in the Irish Hotel Industry. Irish Academy of Management Conference.

Kolb, D. A. (1984). Experiential Learning: experience as a source of learning and development. Englewood Cliffs, New Jersey: Prentice Hall.

Kram, K. E. (1995). Mentoring at work: Developmental relationships in organisational life. Glenview, IL.: Scott Foresman.

Mac Con Iomaire, M. (2001a). An Evaluation of the Professional Internship component of the BA Culinary Arts: An Action Research study of the first and second iterations of the Professional Internship in order to improve practice (Unpublished Thesis), Dublin Institute of Technology.

Mac Con Iomaire, M. (2001b). To investigate what effects (if any) the mentoring programme within the B.A. Culinary Arts Professional Internship is having on the culture of participating establishments (Unpublished HRM research paper), Dublin Institute of Technology.

Mars, G. and M. Nicod (1984). The World of Waiters. London: George Allen \& Unwin.

McCarthy, P. (2003). "Vails and travails: how Lord Kildare kept his household in order." Irish Architectural and Decorative Studies-The Journal of the Irish Georgian Society VI: $120-139$.

McKee, L. (1999). Accelerated Learning. Gower Handbook of Training and Development. A. Landale. Aldershot: Gower.

Mennell, S. (1996). All Manners of Food (Second Edition). Chicago: University of Illinois Press.

Mullins, L. J. (1999). Management and Organisational Behaviour. London: Pitman Publishing.

Murray, M. (1991). Beyond the Myths and Magic of Mentoring. San Francisco, CA.: Jossey-Bass Publishers.

Nelson, A. A. (1997). Hospitality Internships: the effects of job dimensions on student satisfaction. CHRIE Conference Proceedings, Rhode Island.

Parkhurst Ferguson, P. (2006). Antonin Carême. Culinary Biographies. A. Arndt. Houston, Texas, Yes Press: 89-91.

Phillips-Jones, L. (2000). "Why mentoring in these economic times?" http:www.mentoringgroup.com/ideas.html. Retrieved 16 May 2000.

Ramsay, G. (2006). Humble Pie. London: HarperCollins.

Roche, G. R. (1979). "Much ado about mentors." Harvard Business Review 57: 14-28.

Ruhlman, M. (1997). The Making of a Chef. New York: Henry Holt and Company, LLC.

Ruhlman, M. (2001). The Soul of a Chef: The Journey Toward Perfection. New York: Penguin Books.

Schon, D. (1983). The Reflective Practitioner: How Professionals Think in Action. New York: Basic Books.

Toohey, S. (1999). Designing Courses for Higher Education. Buckingham: SRHE and Open University Press. 
Wheaton, B. K. (1983). Savouring the Past: The French Kitchen and Table from 1300-1789. London, Chatto \& Windus: The Hogarth Press.

Wright, S. (2006). Tough Cookies: Tales of obsession, toil and tenacity from Britain's culinary heavyweights. London: Profile Books.

Zey, M. G. (1984). The Mentor Connection. Homewood, IL.: Dow Jones-Irwin. 